\title{
Lithological variations of sedimentary succession within a meteorite impact crater: Jwaneng South Structure, Botswana
}

\author{
Marek Wendorff ${ }^{1}$, Sharad Master ${ }^{2}$ \\ ${ }^{1}$ AGH University of Science and Technology, Faculty of Geology, Geophysics and Environmental Protection, \\ al. A. Mickiewicza 30,30-059 Krakow, Poland; e-mail: wendorff@agh.edu.pl \\ ${ }^{2}$ University of the Witwatersrand, School of Geosciences, Economic Geology Research Institute; \\ Johannesburg, South Africa; e-mail: sharad.master@wits.ac.za
}

(C) 2015 Authors. This is an open access publication, which can be used, distributed and reproduced in any medium according to the Creative Commons CC-BY 4.0 License requiring that the original work has been properly cited.

Received: 2 January 2016; accepted: 4 February 2016

Abstract: The Jwaneng South Structure is a meteorite impact crater located in the Kalahari region of Botswana. The structure has the shape of a bowl $1.3 \mathrm{~km}$ in diameter and a maximum depth of $275 \mathrm{~m}$ in the centre. It was discovered by an airship-mounted full tensor gravity gradiometer and penetrated by nine vertical diamond drillholes. The crater is underlain by the Gaborone Granite (2785 Ma) and basalts of the Karoo Supergroup (182 Ma). The covering aeolian sediments of the Kalahari Group (Late Cretaceous-Recent) completely obscure the structure.

A succession of the following lithofacies overlying authigenic in situ brecciated granite was intersected in the boreholes (from base to top): (i) allogenic heterolithic/oligomictic "fallback" and resedimented breccia (ii) sedimentary breccia and conglomerate with sand matrix; (iii) six intervals of carbonate sediments, with traces of evaporites and mudstone interbeds, which are interlayered with (iv) five intervals of sandstone and sedimentary breccia composed of granules, pebbles and cobbles, mostly of granite, embedded in a matrix of well-sorted medium-grained sand; (v) bioturbated, mostly massive sandstone rich in mud matrix (wacke), with locally preserved interbeds of mudstone and cross-bedded sandstone, and abundant root traces; (v) silcrete and calcrete that occur at the top of the succession.

This lithological association suggests that deposition within the Jwaneng South meteorite impact crater took place in a playa lake surrounded by steeply-dipping talus piedmont fans. The depositional cycles were controlled by pronounced climatic oscillations. Wet periods are recorded by lithofacies (iii), which reflects intense supply of sand eroded from the Kalahari dune field surrounding the crater and coarse detritus derived from its rim and steep talus below. Dry intervals of high evaporation and fall of the lake level are reflected by lithofacies (iv). During the youngest wet period (v) the lake filled up with alluvia sands interbedded with muds, abundantly vegetated and homogenised by bioturbation. The silcrete and calcrete layer at the top of the succession is the product of pedogenic processes that affected the Kalahari Desert environment. An asymmetry of lateral distribution of the lithofacies (ii)-(iv) and the presence of sedimentary breccia redeposited into the marginal E (and NE) parts of the crater suggest an asymmetry of the crater depression and its coarse clastic rim, which may imply an oblique trajectory of the impactor approaching from the SW.

Keywords: meteorite; impact; Kalahari; Jwaneng; sedimentary infill

\section{INTRODUCTION}

The meteorite impact crater named the Jwaneng South Structure was first recorded as a circular geophysical anomaly (Fig. 1) by an airship-mounted full tensor gravity gradiometer in 2006 (Master et al. 2008, 2009, ). It is located in the Kalahari region of Botswana at $\sim 24^{\circ} 46^{\prime} \mathrm{E}, 24^{\circ} 42^{\prime} \mathrm{S}$. In $3 \mathrm{D}$ view, revealed by CSAMT surveys and penetrated by nine vertical diamond boreholes, the structure appears 
to have the shape of a bowl $1.3 \mathrm{~km}$ in diameter and maximum depth of $275 \mathrm{~m}$ in the centre. It is underlain by the Gaborone Granite (2785 Ma) and basalts of the Karoo Supergroup (180 Ma) (Carney et al. 1994, Master et al. 2009). The covering aeolian sediments that completely obscure this structure belong to the Kalahari Group strata, which span an interval from Late Cretaceous to Recent and unconformably overlie older rock complexes (Thomas \& Shaw 1991, Carney et al. 1994, Haddon \& McCarthy 2005).

In the stratigraphic succession, the intact granite underlying the Jwaneng South Structure passes upwards into in situ brecciated granite and mafic rocks overlain by oligomictic allogenic fallback resedimented breccia, in which granite fragments predominate, followed by a succession of poorly lithified sedimentary rocks - both detrital and chemical. Impact-diagnostic planar deformation features (PDFs) have not yet been found, but several other macroscopic and microscopic characteristics are the same as those associated with known impact features and indicate that the Jwaneng South Structure is a buried meteorite impact crater (Master et al. 2008, 2009, Master 2010). The impact origin of the Jwaneng South structure is based on the following evidence: (i) the rocks are completely shattered into angular fragments in the in situ brecciated basement, and into angular, subangular to subrounded clasts (sometimes splinter- to wedge-shaped) in the allogenic breccia, which contains a sandy matrix; (ii) features found in known impact structures are present in individual mineral grains, i.e. mosaicism, deformation bands and lamellae in plagioclase and alkali feldspars, and cleavage in quartz; (iii) macroscopic indicators of shock include "gries"-textured breccias (clasts of which are criss-crossed by very closely-spaced intersecting sets of fractures that break up the rock into lozenges and ultimately into granule-sized grains) and features analogous to shatter cones (multiply-striated joint surfaces, formed by intersecting shock waves); (iv) jigsaw-puzzle breccias in the mafic lavas which are injected by polymictic breccia dykes with fragments surrounded by a fine-grained dark clay rich matrix resembling pseudotachylite (Master 2010).

The dating of the structure is tentative. Sedgelike plant fossils found in lacustrine carbonate rocks in the lower part of the infilling succession suggest a Cenozoic, and most probably Miocene or younger, age of the sediments - therefore they are $<23$ Ma old (Master et al. 2008, 2009 and references therein).

The Kalahari Group sediments (Late Cretaceous to Recent) that cover the Jwaneng South crater form an extensive sedimentary cover on older rock units that extends in the regions of southern and western part of Central Africa (Thomas \& Shaw 1991, Haddon \& McCarthy 2005). The succession represents sediments ranging from fluvial, to lacustrine to aeolian and attains a maximum thickness $>300 \mathrm{~m}$ (Thomas \& Shaw 1991, Carney et al. 1994, Du Plessis \& Le Roux 1995). The youngest facies interval consist of aeolian dune sands (McFarlane \& Eckardt 2006). Effects of pedogenic processes are a common feature expressed by layers of calcrete, silcrete and/or ferricrete (Thomas \& Shaw 1991, Key \& Ayers 2000, Nash \& McLaren 2003).

The Kalahari Group aeolian sediments and the underlying layer of silcrete and calcrete reach maximum thickness of about $30 \mathrm{~m}$ in the area of the Jwaneng impact crater and the underlying $\leq 245 \mathrm{~m}$ thick sedimentary succession that fills the crater records a considerable part of the history of the Kalahari Beds. It is the aim of this paper to present the lithological association of sediments that fill the Jwaneng South Impact Structure and discuss their origins.

Similar small impact structures formed on granitic target rocks are known from southern Africa and elsewhere - e.g., the $3.4 \mathrm{~km}$-diameter Kgagodi Structure, Botswana, filled with Upper Cretaceous to Palaeogene sediments (Brandt et al. 2002); the $1.13 \mathrm{~km}$-diameter, $220 \mathrm{kyr}$-old Tswaing Structure north of Pretoria in South Africa (Partridge 1999), and the $3.8 \mathrm{~km}$-diameter Cambrian Brent structure in Ontario (Dence \& Guy-Bray 1972). Although all these other structures have sedimentary rocks filling the craters, in the first two structures only one borehole has been drilled - allowing only a limited study of sedimentary facies and climatic variations. The Brent Structure has about a dozen drillholes penetrating it, but most studies have concentrated on the impact breccias and target rocks, and no detailed study has been done on the Ordovician sedimentary fill, which shows great similarities with that in the Jwaneng South Structure- including impact and 
talus breccias overlain by evaporitic lacustrine beds, carbonates and sandstones (Dence \& GuyBray 1972). Our study of the sedimentary fill of the Jwaneng South Structure is the first to allow a three-dimensional facies reconstruction of the sedimentary fill of a small simple impact structure formed in granitic target rocks.

\section{METHODS}

The Jwaneng South Structure was originally observed on a Bouguer gravity anomaly map obtain- ed using an airborne full tensor gravity gradiometer (Air-FTG ${ }^{\mathrm{TM}}$ ) (Hatch 2004) mounted on an airship platform. The circular anomaly was also noted on airborne EM, and on images obtained during ground gravity and CSAMT (Controlled Source Audio-Frequency Magnetotelluric) survey along two profiles oriented N-S and E-W. It was further investigated by diamond drilling down to maximum $337 \mathrm{~m}$, with borehole cores 6o $\mathrm{mm}$ in diameter obtained from nine vertical holes sunk along the W-E and N-S cross-section lines (Fig. 1).

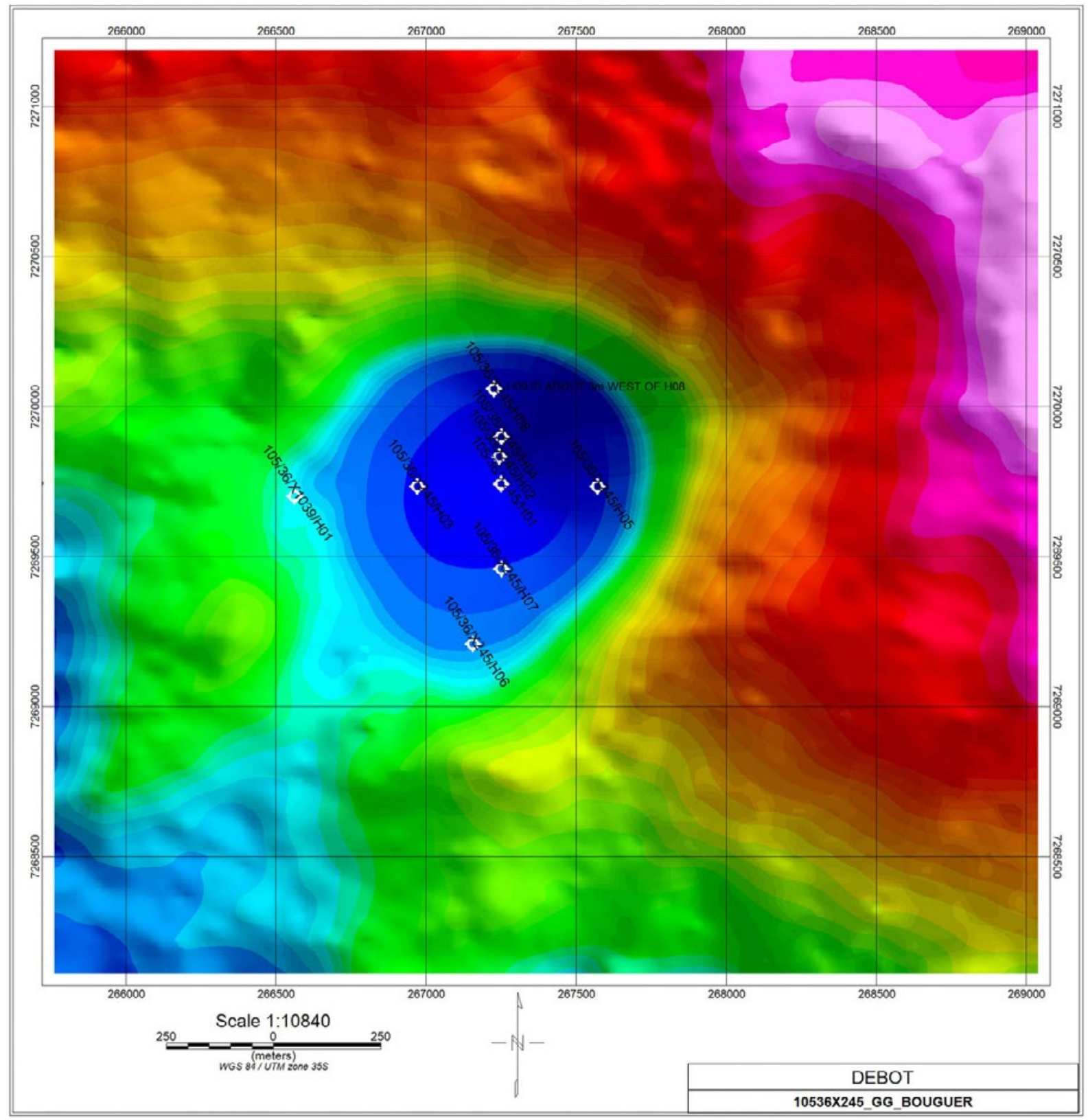

Fig. 1. Airborne Bouguer gravity anomaly map of the Jwaneng South structure. The localities of boreholes are indicated by white stars (after Master et al. 2009) 


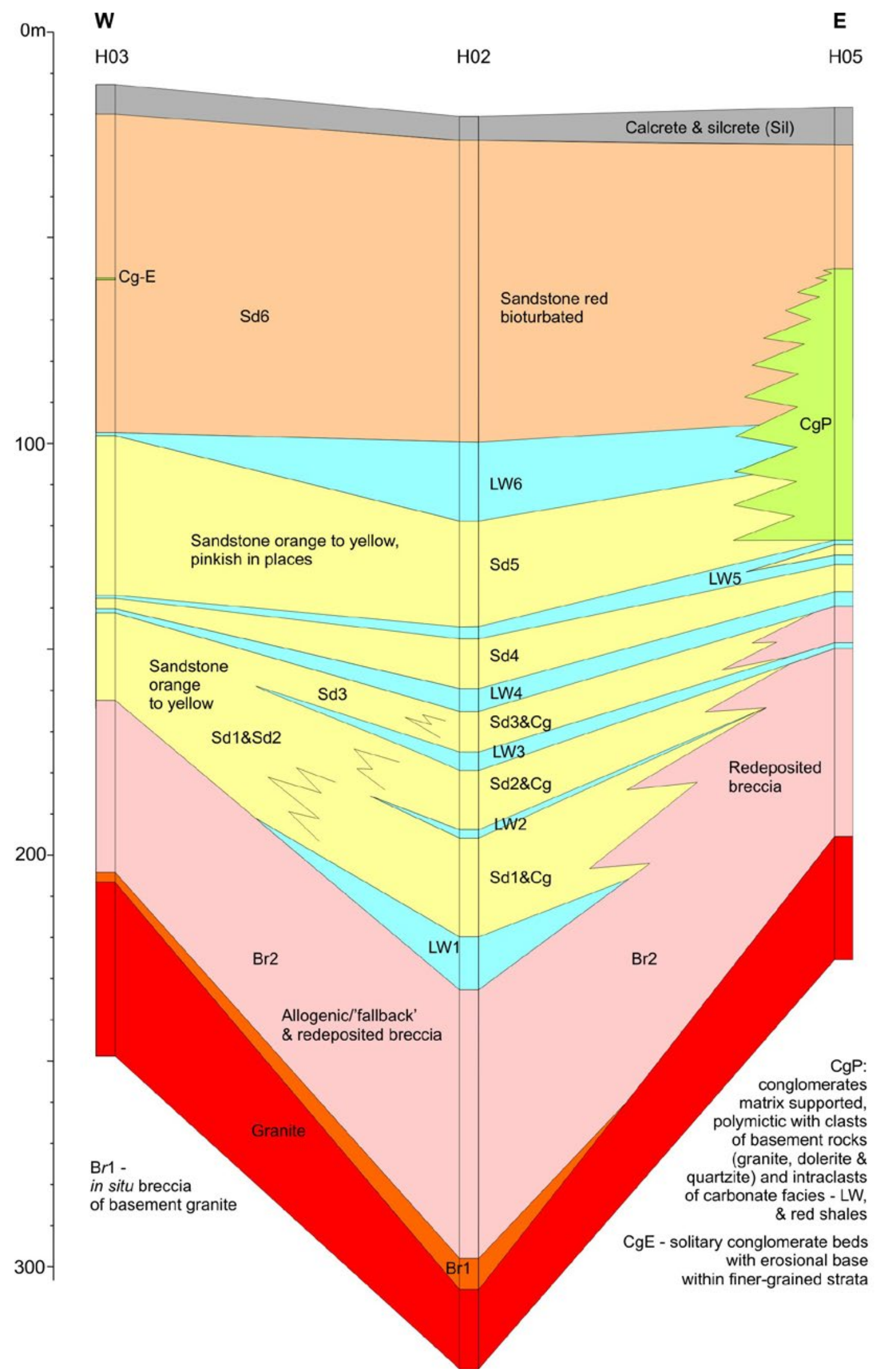

Fig. 2. Lithostratigraphy and lithofacies relations in W-E cross-section as correlated between boreholes H03, H02 and H05 (distance between boreholes - not to scale) 
Sedimentary successions preserved in complete and continuous drill holes were measured in detail (bed-by-bed); observed lithological variations and sedimentary features were photographed. The recorded lithological intervals were subsequently correlated between three borehole cores distributed along the W-E section and compared with the succession present in the $\mathrm{N}$ part of the structure. The latter step was taken in order to substantiate a preliminary observation of asymmetry of lithofacies distribution around the perimeter of the structure.

\section{Lithological succession and sedimentary facies associations}

The discussion below will be based upon the sedimentary successions intersected in three boreholes (H03-H02-H05) distributed along W-E cross-section of the impact structure and two boreholes (H02-H04) along a section running from the centre ( $\mathrm{H} 02)$ to the northern periphery of the structure.

\section{General lithostratigraphy - succession of rock complexes}

In general, the succession preserved in the borehole cores H03-H02-H05 shown in cross-section in Figure 2 unconformably overlies granite basement and consists of the following lithological intervals:

- monomictic and polymictic breccias and locally pink conglomerates ( $\mathrm{Br} 1$ and $\mathrm{Br} 2$ ), overlain by

- a succession of sandstone complexes (Sd 1-Sd 5) containing subordinate sandy pebble- to cobble- conglomerates $(\mathrm{Cg})$, ranging in colour from yellowish to orange and locally pinkish to red;

- laminite complexes (LW 1-LW 6) are interlayered within the sandstone complexes Sd; they are mainly white in colour, characterised by laminated and thinly bedded carbonates, evaporite minerals, early diagenetic silicification and rare fossilized plant detritus;

- strongly bioturbated red sandstone (Sd 6) occurs above the laminite-sandstone complex LW 6;

- partly silicified sandstone, silcrete and silicified calcrete rest at the top of the succession preserved in the borehole cores; it is overlain by ca. $20 \mathrm{~m}$ of unlithified Kalahari sands.

All these lithological intervals are present in borehole cores H02-H04. However, in H05 (Fig. 2) thick intervals of sedimentary breccia and conglomerate occur instead of the youngest $\mathrm{Sd}$ and LW units.

\section{Lithofacies, their associations and genetic interpretations}

\section{Br $1 A$ - breccia}

Basal breccia contains cobbles and boulders to blocks $3 \mathrm{~m}$ in length, as measured along the borehole core, of granite and dolerite embedded in reddish and dark grey muddy matrix containing grains of kaolinised feldspar and angular grains of quartz derived from granite disintegration. Among the clasts are breccias of an older generation in which clasts are cemented by white quartz. The clayey matrix of breccia $\mathrm{Br} 1 \mathrm{~A}$ is a product of granite weathering. In the uppermost part of this complex, the breccia consists of mainly weathered angular clasts of granite contains abundance of matrix of sandy clay, pink in colour.

Interpretation: Authigenic/in situ breccia, via a weathering profile transitional in the lowest part to the basement granite. The uppermost part is weathered and contains admixture of washed-in sandy clay and sand.

\section{Br 2 - breccia}

This breccia contains angular clasts of pebble and cobble size of fresh granite and solitary subangular and subrounded pebbles of the white laminite facies LW of the lithotype that occurs as interbeds at stratigraphically higher levels and is described in the next section (Fig. 3A). The breccia clasts are embedded in matrix of yellow/orange limonitic sandstone, which predominates above as thick complexes forming a majority of the younger part of the succession. In places, the matrix is composed of muddy siltstone. Structurally, the breccia is massive but texturally - a matrix-supported variety prevails.

Interpretation: The sandy matrix, structure and texture suggest that the coarse clasts were transported together with sand as subaqueous debris flows. Intraclasts of the laminite facies that occur within the breccia imply that $\mathrm{Br} 2$ debris flows were entering the basin in which the deposition of LW facies was taking place, or took place prior to erosion by the debris flow. Some debris flows eroded the white laminite facies and incorporated its 
fragments into the volume of the flow. The preservation and shape of the LW intrabasinal clasts (intraclasts) testify to early diagenesis of the laminite sediment prior to erosion and a very short distance between the point of erosion and the site of deposition.

\section{$L W$ - white laminite facies}

White laminite facies association (Fig. 3A, B) is represented by six complexes (LW1-LW6). The summary of its features is given below:

- lithologies:

o chemical sediments - limestone, dolomite, laminae and layers composed of high-Mg calcite, calcarenite, silicified anhydrite, evaporite minerals (incl. small swallow-tail shaped crystals of gypsum), siliceous layers and nodules,

$\circ$ terrigenous and mixed sediments - marl, silty and sandy carbonate, mudstone, siltstone and interbeds of orange sandstone of lithology the same as occurring in the $\mathrm{Sd}$ facies complexes below and above,

o organic component - plant remains, detritus and imprints of stems;

- sedimentary structures: horizontal lamination, thin horizontal bedding, normal grading, wavy lamination, cross lamination of small scale, about $1 \mathrm{~m}$ thick packages of inclined bedding, soft-sediment deformations caused by slumping and loading;

- association boundaries: from sharp to gradational to the underlying and overlying sandstone (Sd facies); the lower boundary of LW 1 in $\mathrm{H} 04$ and $\mathrm{H} 02$ and of LW 03 in $\mathrm{H} 05$ are transitional to the underlying breccia $(\mathrm{Br})$ units.

The LW laminite association shows variations in the vertical sequence of its complexes and especially a decrease in proportion of dolomite, evaporite minerals and siliceous layers, and an increase in proportion of red mudstone laminae up the succession.

Interpretation: In general, the features of the LW facies association imply deposition controlled by high evaporation rates and low influx of terrigenous clastic sediments. The rate of evaporation-controlled sedimentation was low but events of fast deposition of terrigenous material resulted in soft sediment deformations by loading and slumping. Large-scale sets of inclined bedding are composed mainly of micritic carbonate sediment, which at the time of deposition was cohesive carbonate mud and silt. Therefore, such layers could not have been deposited as large cross-bedded bedforms (dunes or 'megaripplemarks') because these are genetically related to traction of non-cohesive sediment. Therefore they are interpreted here as rotational slides - sediment packages rotated by sliding and slumping due to slope instability (Nemec et al. 1988).

The LW facies association was deposited in a subaqueous, shallow, low energy and well oxygenated environment under the influence of moderately weak currents and waves. Intervals of intense evaporation resulted in deposition of calcareous mud, sand (calcarenite) and dolomite. Gypsum and anhydrite crystallised in situ, and in some cases gypsum crystals, some of which are of characteristic type of swallow-tail) were washed off the emergent evaporitic mudflats into the adjacent subaqueous part of the lake. Oscillations in $\mathrm{pH}$ levels of the pore waters resulted in early diagenetic silicification to form siliceous layers or nodular concretions. This evaporative depository was fed periodically with suspended terrigenous mud/pelagic suspension, sand-laden flows and occasional granule to sandy small-scale turbidity currents eroding the underlying fine grained, cohesive carbonate sediments.

Such features are characteristic for lacustrine sedimentation in a saline, evaporitic lake (playa) adjacent to a slope feeding it occasionally in terrigenous sediments.

\section{Sd - Sandstone and conglomerate facies association}

Sandstone facies is represented by six complexes (Sd 1-Sd 6) of orange, pink and red quartzarenite (Fig. 3C). Units Sd 1-Sd 5 consist of mainly medium-grained and well sorted, usually massive sandstone with locally very faint traces of cross-bedding. There are a few occurrences of mottled sandstone with clayey matrix (wacke) and locally preserved bioturbation features. Occurrences of massive wackes (sandstone containing 15-75\% of mud matrix) are noted in unit Sd5 and in LW5 where they occur as subordinate interbeds. At one interval, large-scale cross bedding was observed. Locally, there are intervals $1-3 \mathrm{~m}$ thick of the 

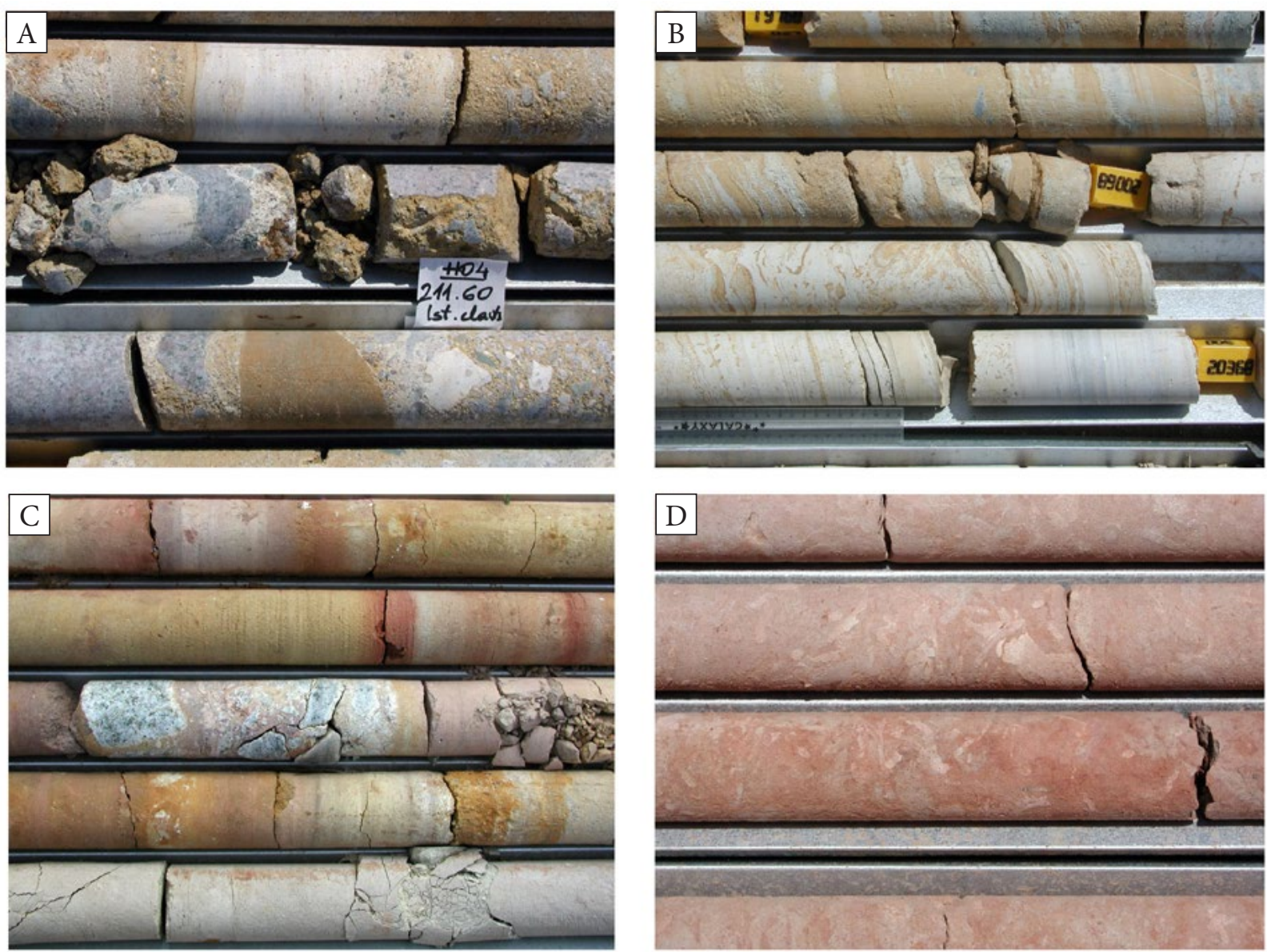

Fig. 3. Examples of the main lithologies in borehole core (core diameter is $6 \mathrm{~cm}$ ). Stratigraphic position in all photographs: stratigraphic top is on the left and core in the uppermost row is the youngest one. For reference to facies complexes-see Figure 2: A) Breccia Br2 underlying the oldest carbonate facies unit LW 1 (upper row) includes carbonate clasts of the LW 1 facies (whitish, subangular and subrounded in the lowest row) demonstrating an earlier deposition of the LW-type sediment, its relatively fast lithification and subsequent erosion by breccia flow. This demonstrates that at least the youngest part of breccia Br 2 is redeposited (borehole H04). B) Laminite complex LW 1 - thin laminae of pelitic carbonate/micrite (white) interbedded with laminae and thin beds of sandstone (orange). Some beds are deformed by slumping (H04). C) Matrix-supported conglomerate with crude inverse grading of granite clasts and abundant sand matrix represents deposition out of debris flow: a thin intercalation in predominantly sandstone complex (Sd facies in H03). D) Red wacke - extremely intensely bioturbated part of unit Sd 6 in which sand was mixed with mud, which resulted in mottled structure and texturally immature bulk composition (H04)

same massive well-sorted sandstone, but containing scattered solitary granules and fine pebbles of granite, subangular and angular in shape. Characteristically, the sandstone quartz grains have frosted surfaces. The youngest sandstone complex (Sd 6) consists of red sandstone enriched in mud matrix (wacke) and is very strongly bioturbated; its uppermost part contains numerous root traces called "pipe sandstone" (Carney et al. 1994).

Conglomerates $(\mathrm{Cg})$ that occur within the sandstone units are matrix-supported with sandy matrix of the same type as the underlying and overlying sandstone. Consequently, tops and bottoms of the conglomerate beds are not defined by bedding surfaces but by either sudden or gradual appearance of coarser clasts. The thickness of these conglomerate beds usually does not exceed $60 \mathrm{~cm}$. The clasts ranging in size from granules to pebbles to subordinate cobbles are composed of fresh granite rarely accompanied by solitary clasts of LW facies and dolerite. The clast shape ranges from angular, to subrounded. The structure of conglomerate beds ranges from inversely graded, which is the most common case, to massive to composite with the lower part graded inversely and the upper part normally graded. Solitary clasts occur as lonestones within the massive sandstone; one occurrence of a granite lonestone was encountered within impure pinkish laminated carbonate sediment. 
Interpretation: Frosted surfaces of quartz sand grains, considered as a result of abrasion during aeolian transport due to dry collisions between grains, and their relatively good sorting suggest derivation from an aeolian environment, probably a dune field covering high ground adjacent to or surrounding the impact crater. Massive structure of sandstone suggests transport by sandy debris flows and rapid deposition. This interpretation finds further support in the sedimentary features of the conglomerates associated with the $\mathrm{Sd}$ facies. Matrix-supported texture, with sandy matrix, and inverse grading are formed by debris flows. In this case these were debris flows rich in liquefied sandy material supporting coarser clasts, probably descending down a subaqueous slope of the depository.

Lonestones, which represent various lithologies, were deposited either as clasts embedded in sandy debris flows or as solitary clasts transported by gravity down the steep slopes towering above the crater bottom. A lonestone that fell upon laminated soft sediment, and was subsequently covered by similar deposit, would appear similar to a glacial dropstone, but the sedimentological context of its occurrence in an evaporative lake does not allow for such an interpretation. Large, outsized boulders which have rolled down the steep crater slopes are present close to the soda lake at the centre of the Tswaing impact structure, and they provide an analogy for the presence of lonestones in the Jwaneng South deposits.

The bioturbated sandstone (Fig. 3D) with root traces (Sd 6), which rest above the complexes described above, and interbeds of wackes, all composed of sand with varying proportions of mud, resulted from post depositional homogenisation by bioturbation of originally interbedded sand and mud layers.

\section{Lateral relations of facies complexes}

\section{Geometry and lateral changes across the structure}

Laterally, along W-E cross-section (Fig. 2), all five complexes of carbonate facies (LW 1-LW 6) and almost all terrigenous complexes (sandstone $\mathrm{Sd}$ and sandstone with conglomerate $\mathrm{Sd} \& \mathrm{Cg}$ ) attain maximum thickness in the centre (borehole $\mathrm{H} 02$ ). As a result of this trend, LW1 has a concave geometry with overlying layers being increasingly flat-lying to the almost flat horizontal upper boundary of LW 6 .

Sandstone complexes containing interbeds of sedimentary breccia (Sd 1 \& Cg-Sd 3 \& Cg) constitute three older detrital intervals present only in the eastern and central parts of the depository. Towards the west they are devoid of sedimentary breccia interlayers. Such a relation of facies correlates very well with the presence of time-equivalent breccia $(\mathrm{Br} 2)$ in the east (borehole $\mathrm{H} 05$ in Figure 3) and lack of thereof in the west, in H03.

Interpretation: Systematic lateral and vertical thickness change of the successive complexes is here attributed to sedimentary compensation, resulting in higher depositional rates in the depocentre than at the margin of the depository.

Lateral change of grain size in sandy complexes is interpreted in terms of uneven distribution of the impact ejecta - breccia clasts - around the crater perimeter. Apparently, the eastern part of the impact structure perimeter acted as a source rich in ejecta, forming a voluminous rim of breccia, and a steep inner slope. On the other hand, the western part of the perimeter must have been devoid of such coarse detritus (a low rim) and the crater slope should have been gentler. In effect, only sand derived from the Kalahari dune filed was washed down into the crater.

\section{Conglomerates in the eastern part of the structure}

In borehole $\mathrm{H} 05$ the unit $\mathrm{Br} 2$ reaches stratigraphically higher than in Boreholes $\mathrm{H} 02$ and $\mathrm{H} 03$, and is time-equivalent to the succession of units LW 1-Sd 3 \& Cg. It is succeeded by laminite LW 4, sandstone, pebbly sandstone and laminite Sd 4-LW 5. The carbonates of laminite LW 5 are interlaminated with pink marl, contain an interbed of sandstone and conglomerate and are succeeded by a younger conglomerate $(\mathrm{CgP})$ supported by sandy matrix.

The younger conglomeratic unit $(\mathrm{CgP})$, in the interval 123.47-57.80 $\mathrm{m}$, rests with erosional base upon the underlying LW 5 and is composed of matrix-supported massive conglomerate with sandy matrix and clasts derived from the basement granite, dolerite and several other stratigraphic units that occur in the region: felsite of the Kanye Volcanics, silicified limestone of the Transvaal 
Supergroup and pebbles derived from the Waterberg Group. It also contains intraclasts of carbonate LW facies. The conglomerate $\mathrm{CgP}$ succession is fining upwards in the upper part and passing to sandstone unit correlative with Sd 6.

Interpretation: Interpretation of breccia $\mathrm{Br} 2$ is discussed earlier in this section, with relation to lateral facies changes. On the other hand, the conglomeratic body CgP present in the younger part of the succession in borehole H05 (Fig. 3) lends further support to the interpretation advanced above that a voluminous rim of breccia and a steep inner slope characterised the eastern part of the impact crater.

\section{DISCUSSION AND CONCLUSIONS}

The sedimentary succession intersected in the discussed boreholes originated in a playa lake characterised by cyclic deposition. The cyclicity was controlled by climatic oscillations with wet periods expressed by Sd \& Cg facies marking lacustrine high stand and LW facies reflecting drying intervals and lacustrine low stand. Wet periods were characterised by high influx of sandy and sandy-gravelly debris flows and high levels of the lake. In dry periods, with lower water level, the deposition was mainly controlled by evaporation accompanied by a limited supply of fine terrigenous detritus - mud and silt.

Coarse extrabasinal clasts (boulders, cobbles, pebbles and granules) were derived from the granitic basement with subordinate contribution of other lithologies that occur in the area - all shattered by impact and accumulated as the crater rim and as 'fallback' scree paving its inner slope prone to erosion, especially at early stages of sedimentation. The sandy component was derived mainly from the Kalahari sand dunes covering the source area adjacent to the lake at the bottom of the crater.

At the last wet stage of evolution the depression of the impact structure was lacking steep slopes, the rim was degraded therefore the crater lake was filled with sandy and muddy sediment (Sd 6) affected by burrowing organisms and covered with rich vegetation, both responsible for bioturbation and the resulting homogenisation. The calcrete and silcrete at the top of the succession result from pedogenic processes that affected the underlying sediments.

In summary, the Jwaneng South structure represents a Late Cenozoic (Miocene or younger) impact crater, formed on the Archaean Gaborone Granite overlain by basalts of early Jurassic age. At intervals, the crater was filled with ephemeral lakes (playa) the carbonate sediments of which record six periods of hot climate and evaporation (Wendorff \& Master 2015). The sandy-conglomeratic/breccia units record high-efficiency supply related to five wet periods, when high-energy discharge from the surrounding terrain washed down the crater slopes sand derived from erosion of the surrounding Kalahari dune field and coarse debris eroded from the crater rim and steeply dipping talus. Such a mechanism of mixing of aeolian sand with coarse clasts is reminiscent of the Kuiseb Valley in Namibia, where the Pleistocene Oswater Conglomerate Formation consists of cobble-pebble-boulder conglomerate associated with aeolian sand (Ward 1987). The coarse clastic components are derived from erosion of the adjacent Great Escarpment - a source of basement rock fragments - and the arenite is sourced from the dune field.

The succession of sedimentary breccias that appear in the eastern part of the Jwaneng South crater synchronously with the finer-grained succession filling most of its volume suggest an asymmetry of the depository. Namely, it is inferred that the eastern slope was much steeper than the remaining part of the impact perimeter and/or the eastern part of the rim composed of coarse debris was much higher. A marked asymmetry of distribution of signatures depicted in the Bouguer gravity anomaly map (Fig. 1) lends further support to this suggestion advanced on the basis of lithological relationships. This asymmetry may suggest an oblique trajectory of the approaching impactor, inclined towards the north-east.

We thank De Beers Botswana Prospecting Pty Ltd for allowing us to publish these data and are grateful to the Editor and two anonymous reviewers for constructive comments.

Preparation of the results for publication was funded by the AGH Statutory Grant 11.11.140.175 to MW.

\section{REFERENCES}

Brandt D., Holmes H., Reimold W.U., Paya B.K., Koeberl C. \& Hancox P.J., 2002. The Kgagodi Basin: the first impact structure recognised in Botswana. Meteoritics and Planetary Science, 37(12), 1765-1779. 
Carney J., Aldiss D. \& Lock N., 1994. The Geology of Botswana. Bulletin, 37, Geological Survey of Botswana, Lobatse.

Dence M.R. \& Guy-Bray J.V., 1972. The Brent Crater. [in:] Some Astroblemes, Craters, and Cryptovolcanic Structures in Ontario and Quebec. International Geological Congress, Twenty-Fourth Session, Canada 1972, Field Excursion, 11-18.

Du Plessis P.I. \& Le Roux J.P., 1995. Late Cretaceous alkaline saline lake complexes of the Kalahari Group in northern Botswana. Journal of African Earth Sciences, 20(1), 7-15.

Haddon I.G. \& McCarthy T.S., 2005. The Mesozoic-Cenozoic interior sag basins of Central Africa: The Late-Cretaceous-Cenozoic Kalahari and Okavango basins. Journal of African Earth Sciences, 43, 316-333.

Hatch D., 2004. Evaluation of a full tensor gravity gradiometer for kimberlite exploration. [in:] Lane R.J.L. (ed.), Airborne Gravity 2004 -Abstracts from the ASEG-PESA Airborne Gravity 2004 Workshop, Geoscience Australia Record, 2004/18, 173-180.

Key RM \& Ayres N. 2000 The 1998 edition of the National Geological map of Botswana. Journal of African Earth Sciences, 30(3), 427-451 with CD.

Master S., 2010. Fractured basalt and mafic breccia dikes from the buried $1.3-\mathrm{km}$ diameter Jwaneng South Structure, Botswana. [in:] Abstract, Session P05: Impact Cratering on Solid Planets - Shocks on Basalt. American Geophysical Union, 'The Meeting of the Americas', 8-13 August 2010, Foz do Iguaçu, Brazil, P43A-08.

Master S., Wendorff M. \& Pitts B., 2008. Jwaneng South Structure, Botswana: a new $1.2 \mathrm{~km}$ diameter buried Cenozoic impact crater. [in:] 33rd International Geological Congress, Oslo, 4-14 August 2008, Thematic Session: PIS-01:
General contributions to impact structures. Abstracts on CD-ROM.

Master S., Pitts B. \& Wendorff M., 2009. Jwaneng South Structure, Botswana: a new $1.3 \mathrm{~km}$ diameter buried Cenozoic impact crater discovered by airship-mounted gravity gradiometer. [in:] Vogt D. \& Fourie C.J.S. (eds), 11th SAGA Biennial Technical Meeting and Exhibition Swaziland, 16-18 September 2009, 97-100.

McFarlane M.J. \& Eckardt F.D., 2006. The 'Transparent' Linear Dunes of Northwest Ngamiland, Botswana. Botswana Notes \& Records, 36, 136-139.

Nash D.J. \& McLaren S.J., 2003. Kalahari valley calcretes: their nature, origins and environmental significance. Quaternary International, 111, 3-22.

Nemec W., Steel R., Gjelberg J., Collinson J.D., Prestholm E., Oxnevald I.E. \& Worsely D., 1988. Exhumed rotational slides and scar infill features in a Cretaceous delta front, eastern Spitsbergen. Polar Research, 6, 105-112.

Partridge T.C. (ed.), 1999. Tswaing: Investigations into the Origin, Age, and Palaeoenvironments of the Pretoria Saltpan. Council for Geoscience: Memoir, 85, Council for Geoscience, South Africa.

Thomas D.G.S. \& Shaw P.L., 1991. The Kalahari Environment. Cambridge Uiversity Press, Cambridge.

Ward J.D., 1987. The Cenozoic succession in the Kuiseb Valley, Central Namib Desert. Geological Survey Namibia: Memoir, 9, Geological Survey, Department of Economic Affairs.

Wendorff M. \& Master S., 2015. Cyclic lacustrine sedimentation in a meteorite impact crater: the Jwaneng South Structure in the Kalahari, Botswana (SW Africa). [in:] $31^{\text {st }}$ IAS Meeting of Sedimentology, Kraków 22 June 2015: abstracts, Polish Geological Society, Kraków. 